vùng cổ, chiếm $68,5 \%{ }^{8}$.

Trong nhóm bệnh nhân nghiên cứu, kích thước u trung bình là $19,1 \pm 11,4 \mathrm{~mm}$, u đơn độc chiếm $76,5 \%$. Kết quả của chúng tôi tương tự Lee $\mathrm{S}$. và cộng sự với kích thước u là $21 \pm 17 \mathrm{~mm}$, u 1 thùy chiếm $61,4 \%$. So với với ung thư giáp thể nhú, ung thư giáp thể tủy có kích thước lớn hơn có ý nghĩa thống kê, đường kính $2,3 \pm 1,5$ so với 1,1 $\pm 1,1 \mathrm{p}=0,001^{9}$. Trong nhóm ung thư tuyến giáp thể tủy di truyền tỉ lệ di căn hạch cổ trung tâm đơn thuần $45 \%$, di căn hạch cổ cùng bên $36 \%$, di căn hạch cổ đối bên 19\%. Trong nhóm ung thư tuyến giáp thể tủy lẻ tẻ tỉ lệ di căn hạch cổ trung tâm đơn thuần $50 \%$, di cằn hạch cổ cùng bên $57 \%$, di căn hạch cổ đối bên $28 \% 3$.

\section{KẾT LUÂ̂N}

Tuổi mắc bệnh trung bình là 48,1 $\pm 11,2$ tuổi, phần lớn trong nhóm 40-65 tuổi (chiếm 67,6\%). Tỉ lệ nữ/nam là $1 / 1,26$. Đa số bệnh nhân khám sức khỏe định kỳ phát hiện có u giáp chiếm tỉ lệ $55,9 \%$. Khối u chủ yếu ở 1 thùy $(85,3 \%)$, kích thước $\leq 2 \mathrm{~cm}(55,9 \%)$. Đánh giá trên siêu âm chủ yếu là TIRADS $4(76,5 \%)$. Tî lệ chọc hút tế bào kim nhỏ chẩn đoán ung thư tuyến giáp thể tủy hoặc nghi ngờ ung thư tuyến giáp thể tủy là $55,9 \%$.

Tỉ lệ di căn hạch chung là $47,1 \%$, tỉ lệ di căn hạch cổ nhóm 6 đơn thuần và kèm theo hạch cổ bển lần lượt là $31,2 \%$ và $62,5 \%$. Tỉ lệ di căn hạch tiềm ẩn là $21,1 \%$. Ung thư tuyến giáp thể tủy ở nam giới làm tăng tỉ lệ di căn hạch có ý nghĩa thống kê $(p<0,05)$.

TÀI LIẸU THAM KHẢO

1. Nguyễn Bá Đức. Dịch tễ học bệnh ung thư. Nhà xuất bản Y học; 2008.

2. Ricardo VL, Y.Osamura R. WHO classification of tumours of endocrine organs. IARC. 2017.

3. Scollo C, Baudin E, Travagli JP, et al. Rationale for central and bilateral lymph node dissection in sporadic and hereditary medullary thyroid cancer. J Clin Endocrinol Metab. 2003;88(5):2070-2075.

4. Roman S, Lin R, Sosa JA. Prognosis of medullary thyroid carcinoma: demographic, clinical, and pathologic predictors of survival in 1252 cases. Cancer. 2006;107(9):2134-2142.

5. Thyroid Cancer. NCCN guideline version 1. 2019.

6. Raue F. German medullary thyroid carcinoma/multiple endocrine neoplasia registry. German MTC/MEN Study Group. Medullary Thyroid Carcinoma/Multiple Endocrine Neoplasia Type 2. Langenbecks Arch Surg. 1998;383(5):334-336.

7. Milano AF. Thyroid Cancer: 20-Year Comparative Mortality and Survival Analysis of Six Thyroid Cancer Histologic Subtypes by Age, Sex, Race, Stage, Cohort Entry Time-Period and Disease Duration (SÉER*Stat 8.3.2) A Systematic Review of 145,457 Cases for Diagnosis Years 1993-2013. J Insur Med. 2018;47(3):143-158.

8. Lê Văn Quảng. Nhân xét đặc điểm lâm sàng và các phương pháp điều trị ung thư tuyến giáp tại Bênh viên $\mathrm{K}$ từ năm 1992-2000. Tạp Chí Y Học. 2002:323-326.

9. Lee S, Shin JH, Han BK, Ko EY. Medullary thyroid carcinoma: comparison with papillary thyroid carcinoma and application of current sonographic criteria. AJR Am J Roentgenol. 2010;194(4):1090-1094.

\title{
NGHIÊN CỨU MộT Số ĐĂC ĐIỂM LÂM SÀNG VÀ ĐộT BIẾN GEN TRÊN BỆNH NHẦ PARKINSON KHỞI PHÁT SỚM
}

\section{TÓM TẮT}

Đặt vấn đề: Trong những năm gần đây, bệnh Parkinson là đề tài mũi nhon đối với các bệnh thoái hoá thần kinh. Bệnh phổ biển thứ hai sau Alzeimer và chiếm $1,6 \%$ so với các bênh thân kinh. Trong bênh Parkinson, đột biến gen lặn tự phát có thể làm tẳng nguy cơ mắc Parkinson ớ người trẻ, ngay cả khi chi thừa hưởng môt bản sao của gen đột biến. Mục tiêu: Mô tả một sổ đặc điểm lâm sàng của bênh nhân Parkinson khởi phát sớm và mô tả một số đột biến gen trên bệnh nhân Parkinson khởi phát sớm. Đối

*Trường Đại học Y Hà Nội

Chịu trách nhiệm chính: Tô Thị Thu Hương

Email: dr.tohuong@gmail.com

Ngày nhận bài: 13.7.2021

Ngày phản biên khoa học: 8.9.2021

Ngày duyệt bài: 15.9.2021

\section{Tô Thị Thu Hương*, Nguyễn Văn Liệu*}

tượng và phương pháp nghiên cứu: nghiên cứu mố tả cắt ngang trên 30 bênh nhân có tuổi khởi phát nhỏ hơn 50 được chẩn đoán mắc bệnh Parkinson nguyên phát theo tiêu chuẩn của Ngân hàng Não thuộc Hội bệnh Parkinson Vương quốc Anh tại bệnh viện Lão Khoa trung ương, bệnh viện Bạch Mai. Trung tâm nghiên cứu Gen- Protein trường đại học $Y$ Hà Nội, nơi tiến hành các kỹ thuật di truyền phân tử. Kềt quả: tuổi khởi phát trung bình 41 với tỷ lệ nam: nữ là 1,9. Triệu chứng run hay gặp nhất với tỷ lệ 93,8\%. Và đột biến gen hay gặp là GBA phát trẻ

Tư khóa: Parkinson, đột biến gen, Parkinson khởi

\section{SUMMARY}

\section{THE STUDY SOME CLINICAL CHARACTERISTICS AND MUTATION IN EARLY-ONSET PARKINSON PATIENTS}


Background: Studies about Parkinson have recently become a key topic among neurodegenerative status research. The disease was ranked at the second highest prevalence accounting for $1.6 \%$ of all neurological diseases In Parkinson's disease, an autosomal recessive gene mutation can increase a young person's risk of Parkinson's, even if only one copy of the mutated gene is inherited. Objectives: Describe some clinical features of patients with earlyonset Parkinson's disease and describe some mutations in patients with early-onset Parkinson's disease. Methods: This is a cross-sectional study conducted among 30 Parkinson patients who were initially diagnosed with primary Parkinson, based on criteria for Parkinson diagnosis of the Brain bank of the Parkinson Disease Society in the United Kingdom, at the age of less than 50 years old in the National Geriatric hospital, Bach Mai hospital. Results: The mean age of onset was 41 with a male:female ratio of 1.9. The symptom of tremor at rest was the most common with the rate of $93.8 \%$. And the most common gene mutation is GBA

Key word: Parkinson, mutation, early-onset parkinsonism.

\section{I. ĐĂT VẤN ĐỀ}

Trong những năm gần đây, bênh Parkinson là đề tài mũi nhọn đối với các bệnh thoái hoá thần kinh. Bệnh phổ biến thứ hai sau Alzeimer và chiếm $1,6 \%$ so với các bệnh thần kinh. Bệnh Parkinson là do sự mất dopamin của hạch nền, gây nên các triệu chứng đặc trưng của bệnh: chậm chạp, cứng, run khi nghỉ và rối loạn phản xạ tư thể dáng đi. Ngoài ra, nhiều nghiên cứu cũng quan sát thấy ở các bệnh nhân bị Parkinson có quá trình oxy hóa protid, lipid tăng cao bất thường, đồng nghĩa với việc một lượng lớn các gốc tự do đước sản sinh trong khu vực não bộ. Trên thế giới, các nghiên cứu gần đây cũng cho thấy di truyền đóng vai trò quan trọng có thể làm tăng nguy cơ mắc Parkinson ở người trẻ. Với mong muốn đóng góp thêm những hiểu biết về bệnh Parkinson ở Việt Nam, chúng tôi tiến hành nghiên cứu đề tài: "Nghiên cứu một số đặc điểm lâm sàng và đột biến gen trền bệnh nhân Parkinson khởi phát sớm"

\section{II. ĐỐI TƯỢNG VÀ PHƯƠNG PHÁP NGHIÊN CỨU}

Đối tượng nghiên cứu. Gồm 32 bệnh nhân điều trị tại bệnh viện Bạch Mai, Lão Khoa, từ tháng 10/2019 đến tháng 6/2021

Tiêu chuẩn lựa chọn bệnh nhân. Bệnh nhân được chẩn đoán mắc bệnh Parkinson nguyên phát theo tiêu chuẩn của Ngân hàng Não thuộc Hội bệnh Parkinson Vương quốc Anh, có tuổi khởi phát nhỏ hơn 50, giới, nghề nghiệp được chọn ngẫu nhiên trong quá trình nghiển cứu, thỏa mãn tiêu chuẩn chẩn đoán. Các bệnh nhân đều được chụp cộng hưởng từ hoặc cắt lớp vi tính sọ não và có kết quả bình thường

Phương pháp nghiên cứu: mô tả cắt ngang

Xử lý số liệu: phần mềm EPIDATA 3.1 VÀ IBM SPSS 16.0.

\section{KẾT QUẢ NGHIÊN CỨU}

\subsection{Một số đặc điểm lâm sàng}

Bảng 1 Phân bố bệnh nhân theo tuổi khởi phát bệnh và giới

\begin{tabular}{|c|c|c|c|c|c|c|}
\hline \multirow{2}{*}{ Nhóm tuối } & \multicolumn{2}{|c|}{ Nam } & \multicolumn{2}{c|}{ Nũ̃ } & \multicolumn{2}{c|}{ Tống } \\
\cline { 2 - 7 } & $\mathbf{n}$ & $\mathbf{0}$ & $\mathbf{n}$ & $\mathbf{\%}$ & $\mathbf{n}$ & $\mathbf{\%}$ \\
\hline Tuối trung bình & 41.7 & & 42.8 & & 42.1 & \\
\hline $45-\leq 50$ & 7 & 21.9 & 4 & 12.5 & 11 & 34.4 \\
\hline $40-\leq 45$ & 4 & 12.5 & 4 & 12.5 & 8 & 25.0 \\
\hline $35-\leq 40$ & 4 & 12.5 & 2 & 6.3 & 6 & 18.8 \\
\hline $30-\leq 35$ & 6 & 18.8 & 1 & 3.1 & 7 & 21.9 \\
\hline Tống & $\mathbf{2 1}$ & $\mathbf{6 5 . 6}$ & $\mathbf{1 1}$ & $\mathbf{3 4 . 4}$ & $\mathbf{3 2}$ & $\mathbf{1 0 0}$ \\
\hline
\end{tabular}

Kết quả khảo sát cho thấy nam giới chiếm đa số (65.6\%), nữ giới chiếm ít hơn (34.4\%). Độ tuố trung bình của nhóm bệnh nhân khảo sát 42.1 tuổi. Nhóm bệnh nhân có tuổi khởi phát thuộc nhóm 45 - $\leq 50$ nhiêu nhất (34.4\%), nhóm bệnh nhân có tuổi khởi phát thuộc nhóm 35 - $\leq 40$ ít nhất (18.8\%)

Bảng 2: Triệu chứng về vận động

\begin{tabular}{|c|c|c|c|}
\hline \multirow{2}{*}{\multicolumn{2}{|c|}{$\begin{array}{c}\text { Triệu chứng } \\
\text { Giảm động }\end{array}$}} & $\mathbf{n}$ & $\%$ \\
\hline & & 29 & 90.6 \\
\hline Cứng & & 28 & 87.5 \\
\hline Run & & 30 & 93.8 \\
\hline Tống s & ệnh nhân & 32 & \\
\hline
\end{tabular}

Trong tống số 32 bệnh nhân tham gia nghiên cứu, có $90,6 \%$ bệnh nhân có triệu chứng về giảm động; $87,5 \%$ bệnh nhân có triệu chứng cứng; $93,8 \%$ bệnh nhân có biểu hiện run.
Bảng 3: Triệu chứng ngoài vận động tại thời điểm khởi phát

\begin{tabular}{|c|c|c|}
\hline Triệu chứng & $\mathbf{n}$ & $\mathbf{\%}$ \\
\hline Trầm cảm & 10 & 31,2 \\
\hline Tăng tiết nước bọt & 6 & 18,8 \\
\hline Táo bón & 11 & 34,4 \\
\hline Rối loạn ngứí & 8 & 25,0 \\
\hline Rối loạn điều hòa thân nhiệt & 8 & 25,0 \\
\hline Ngã & 6 & 18,8 \\
\hline
\end{tabular}




\begin{tabular}{|c|c|c|}
\hline Rối loạn giấc ngủ & 19 & 59,4 \\
\hline $\begin{array}{c}\text { Số bệnh nhần có triệu } \\
\text { chứng ngoài vận động }\end{array}$ & $\mathbf{2 8}$ & $\mathbf{8 7 . 5}$ \\
\hline
\end{tabular}

Trong tổng số 32 bệnh nhân nghiên cứu, có 28 bệnh nhân có triệu chứng ngoài vận động chiếm $87,5 \%$. Trong đó triệu chứng về táo bón (34,4\%)và rối loạn giấc ngủ $(59,4 \%)$ chiếm tỷ lệ cao nhất

\begin{tabular}{|c|c|c|}
\hline Loai đôt biên & $\mathbf{n}$ & $\%$ \\
\hline PARKIN & 2 & 6,3 \\
\hline GBA & 7 & 21,9 \\
\hline LRRK2 & 1 & 3,1 \\
\hline DNAJC6 & 1 & 3,1 \\
\hline EIF4G1 & 4 & 12,5 \\
\hline SYNJ1 & 1 & 3,1 \\
\hline GIGYF2 & 5 & 15,6 \\
\hline SNCA & 1 & 3,1 \\
\hline
\end{tabular}

Trong số 32 bênh nhân tham gia nghiên cứu, 18 bệnh nhân có đột biến gen chiếm $56,3 \%$. Trong đó, đột biến hay gặp nhất là GBA (21.9\%),

\section{BÀN LUẬN}

\section{1 Đặc điểm lâm sàng}

- Phân bố bệnh nhân khởi phát theo tuổi, tuổi trung bình 41 , (tuổi cao nhất 50 tuổi thấp nhất 30). Lứa tuổi hay gặp nhất trong nghiên cứu là 45-50. Sự khởi phát của bênh Parkinson vô căn xảy ra ở tuổi trưởng thành và có tỷ lệ mắc cao nhất từ 50-69 tuổi. Tuy nhiên vẫn có rất nhiều trường hợp các bệnh nhân dưới 30 hoặc 40 tuổi có các triệu chứng giống Parkinson xuất hiện do đó được định nghĩa là "Parkinson khởi phát sớm". Bệnh Parkinson có tỉ lệ mắc tăng theo tuổi, tỷ lệ của nhóm Parkinson khởi phát sớm nhìn chung thấp hơn tỷ lệ của nhóm Parkinson khởi phát ở độ tuổi lớn hớn (8). Trong nghiên cứu xuất bản năm 2016, tác giả Gennaro Pagano đã dựa trên cơ sở dữ liệu của 422 bệnh nhân Parkinson để phân thành bốn nhóm khác nhau gồm khởi phát trước 50 tuổi, từ 50-59 tuổi, từ 60 đến 69 tuổi và từ 70 tuổi trở lên. Kết quá chỉ có 58 bệnh nhân khởi phát trước 50 tuổi, chiếm $13,74 \%$, có 117 bệnh nhân thuộc nhóm thứ 2, chiếm $27,73 \%$, có 168 bệnh nhân ở nhóm thứ 3 , chiếm $39,81 \%$, nhóm còn lại có 79 bênh nhân, chiếm $18,72 \%$. Như vậy nhóm bệnh nhân khởi phát trước 50 tuổi chiếm tỉ lệ thấp nhất trong 4 nhóm(1). Trong một nghiên cứu ở Colombia công bố năm 2020 với mẩu số lớn gồm 3264 bệnh nhân Parkinson, kết quả cũng cho thấy có sự khác biệt lớn về tỉ lệ độ tuổi mắc PD tại thời điểm nghiển cứu. Nhóm tuổi 30-39 tuổi chỉ chiếm 0,21\%, nhóm tuổi 40-49 chỉ chiếm
3,25\%, trong khi nhóm tuổi 70-79 tuổi có tỉ lệ cao nhất với $34,1 \%$ (9). Trong nghiên cứu tổng hợp ở nhiều quốc gia ở nhiêu châu lục khác nhau, sau khi cộng gộp số liệu, kết quả cho thấy trung bình nhóm nhóm dân số từ 40-49 tuổi thì chỉ có 41/100.000 người mắc Parkinson (9).

- Phân bố bệnh nhân theo giới tỷ lệ nam : nữ là: $1,9: 1$ cũng phù hợp với hẩu hết các nghiên cứu. Nghiên cứu gần đây với số lượng lớn bệnh nhân Parkinson của Yasuhiko Baba và cộng sự là 1264 bệnh nhân, tỉ lệ về giới giữa nam:nữ là 2,03: 1, tỉ lệ này ở những bệnh nhân khởi phát trước 40 tuổi là 1,8:1 (5). Còn theo tác giả Gennaro Pagano tỷ lệ nam: nữ mắc bệnh Parkinson ở bệnh nhân dưới 50 tuổi là 1,7: 1 (1)

- Triệu chứng về vận động tại thời điểm khám bệnh: triệu chứng run khi nghỉ chiếm tỷ lệ cao nhất $93,8 \%$. Theo nghiên cứu tác giả Gennaro Pagano, tỷ lệ cứng chiếm tỷ lệ cao nhất $94,8 \%$, sau đó là giảm động $86,2 \%$, run khi nghỉ $72,4 \%$ và mất ổn định tứ thế $5,4 \%$. Và tác giả này cũng chỉ ra rằng phân nhóm tuổi khởi phát sớm dưới 50 tuổi tỷ lệ độ cứng chiếm tỷ lệ cao hơn hẳn so với các phân nhóm tuổi khởi phát khác ( $\mathrm{p}=$ $0,003)(1)$

- Triệu chứng ngoài vận động tại thời điểm khám bệnh: triệu chứng về táo bón $(34,4 \%)$ và rối loạn giấc ngủ $(59,4 \%)$ chiếm tỷ lệ cao nhất. Theo Gennaro Pagano, rối loạn về ngửi: $26,33 \%$ chiếm tỷ lệ cao nhất, sau đó là rối loạn thần kinh tự chủ: 6,98\%; rối loạn giấc ngủ REM: 5,6\% . Các triệu chứng ngoài vận động ngày càng được công nhận là các yếu tố quan trọng trong phổ lậm sàng của Parkinson (1). Nhiều mối quan tâm gần đây đã tập trung vào tầm quan trọng của mất khứu giác, táo bón, rối loạn thần kinh giao cảm tim, rối loạn hành vi giấc ngủ REM (RBD) có thể là dấu hiệu tiềm ẩn của PD mới khởi phát hoặc "tiền lâm sàng", đây có thể là dấu hiệu của thời gian đầu hoặc thậm chí nhiều thập kỷ trước khi xuất hiện các triệu chứng vân động cổ điển $(6,7)$

4.2 Đặc điểm đột biến gen. Trong nghiên cứu này, tỷ lệ bệnh nhân đột biến chiếm: $56,3 \%$; Với các gen đột biến chủ yếu: GBA (21.9\%), đứng thứ hai là bệnh nhân có đột biến GIGYF2 $(15,6 \%)$, đứng thứ ba là bệnh nhân có đột biến EIF4G1 $(12,5 \%)$. Theo một nghiên cứu của tác giả Roy N. Alcalay và cộng sự trên 953 người gốc Tây Ban Nha và gốc Do Thái được chẩn đoán Parkinson với tuổi khởi phát trước 51 . Tỷ lệ người tham gia có đột biến gen 158 người chiếm $16,6 \%$. Trong số này tỷ lệ đột biến gen LRRK2 là 6,7\%, đột biến GBA: 6,7\%, PRKN:6,7\% (2). Theo Emil K. nghiên cứu trên 108 bệnh nhân 
Parkinson người Nauy với tuổi khởi phát dưới 45, tỷ lệ đột biến gen $14 \%$. Tỷ lệ bệnh nhân đột biến gen của chúng tôi cao hơn so với các tác giả, nhưng cõ̃ mẫu của chúng tôi rất nhỏ so với các tác giả trên. Vì vậy đây chưa phải là con số đại diện cho tỷ lệ đột biến gen trên bện nhân Parknson khởi phát sớm tại Việt Nam. Đột biến trong LRRK2 có thể chiếm 5-6\% Parkinson có tiền sử gia đình và $1-2 \%$ các trường hợp Parkinson nghiên cứu lẻ tẻ. Đối với gen EIF4G1, đây là một gen mới di truyền trội nằm trên NST thường của gen PARK18. Theo tác giả Deng $\mathrm{H}_{\text {, }}$ tỷ lê bênh nhân Parkinson bị đột biến gen này dưới $1 \%$. Và cũng theo tác giả này, trong một nghiên cứu kết hợp nhiều tác giả trên khắp thế giới với cõ̃ mẫu 9422 bênh nhân Parkinson, thì phát hiện 22 bệnh nhân có đột biến chiếm tỷ lệ 0,23\% (4). GIGYF2 thuộc locus PARK11, gồm 27 exon mã hóa cho 1299 acid amin. Điều đăc biêt đây là gen gây bênh Parkinson khởi phát muộn (3). Nhưng trong nghiên cứu của mình, chúng tôi gặp 27,8\% bệnh nhân khởi phát sớm trước 50 tuổi mang gen này. Đây có thể là tiền đề mới cho các nghiên cứu đi sâu về gen trong tương lai.

\section{KẾT LUÂN}

- Tuổi khởi phát trong nhóm bệnh từ 45-50 là cao nhất

- Bệnh gặp ở nam nhiều hơn nữa với tỷ lệ: 1,9

- Triệu chứng lâm sàng gặp tại thời điểm khám bệnh: triệu chứng run chiếm ưu thế

- Triệu chứng lâm sàng ngoài vận động tại thời điểm khám bệnh rất đa dạng trong đó rối loạn giấc ngủ gặp thường xuyên.
- Có 18 bệnh nhân bi đột biến gen chiếm $56,2 \%$. Trong đó tỷ lệ đột biến GBA cao nhất. Đây là một trong các gen gây bệnh Parkinson khởi phát sớm. Xét nghiêm di truyền có thể hữu ích trong trong viêc tư vấn di truyên đối với bênh nhân Parkinson khởi phát sớm và có thể giúp hỗ trợ chẩn đoán phân biệt, dự đoán tiên lượng bệnh và đáp ứng với điều trị

\section{TÀI LIẸU THAM KHẢO}

1. Gennaro Pagano, MD Nicola Ferrara, MD David J. Brooks, MD, DSc Nicola Pavese, MD, PhD. (2016) Age at onset and Parkinson disease phenotype, Neurology 86 April 12, 2016

2. Roy N. Alcalay, MD, MSc; Elise Caccappolo, PhD và cộng sự. Frequency of Known Mutations in Early-Onset Parkinson Disease. Arch Neurol. 2010; 67(9):1116-1122

3. Suganya Selvaraj, Shanmughavel Piramanayagam. Impact of gene mutation in the development of Parkinson's disease. Genes and diseases (2019) 6, 120-128

4. Deng $\mathbf{H}, \mathbf{W u} \mathbf{Y}$, Jankovic J. The EIF4G1 gene and Parkinson's disease. Acta Neurol Scand 2015: 132: 73-78 DOI: 10.1111/ane.12397, 73-78

5. Baba, Y., et al., Gender and the Parkinson's disease phenotype. Journal of neurology, 2005 252(10): p. 1201-1205

6. Abbott, R.D., et al., Frequency of bowel movements and the future risk of Parkinson's disease. Neurology, 2001. 57(3): p. 456-462.

7. Iranzo, A., et al., Rapid-eye-movement sleep behaviour disorder as an early marker for a neurodegenerative disorder: a descriptive study. The Lancet Neurology, 2006. 5(7): p. 572-577.

8. Giovannini, $\mathbf{P}_{\text {., }}$ et al., Early-onset Parkinson's disease. Movement disorders: official journal of the Movement Disorder Society, 1991. 6(1): p. 36-42.

9. Orozco, J.L., et al., Parkinson's disease prevalence, age distribution and staging in Colombia. Neurology International, 2020. 12(1): p. 9-14.

\title{
ĐĂC ĐIỂM LÂM SÀNG VÀ YẾU TỐ TIÊN LƯƠ'NG TRANG THÁI CAI RƯỢU Ở BỆNH NHÂN ĐIỀU TRI NộI TRÚ
}

\author{
Bùi Nguyễn Hồng Bảo Ngọc ${ }^{1}$, Vũ Thy Cầm ${ }^{1}$, Nguyễn Kim Việt ${ }^{1,2}$
}

\section{TÓM TẮT}

Các bênh nhân được điêu trì trạng thái cai rượu có thể xuất hiện một số biến chứng nguy hiểm đe dọa tính mạng như sảng run, co giật, mê sảng với co

${ }^{1}$ Viện Sức khỏe Tâm thần-Bệnh viện Bạch Mai ${ }^{2}$ Trường Đai hoc Y Hà Nôi

Chịu trách nhiệm chính: Bùi Nguyễn Hồng Bảo Ngọc Email: bsbuibaongoc@gmail.com

Ngày nhận bài: 12.7.2021

Ngày phản biện khoa học: 6.9.2021

Ngày duyệt bài: 13.9.2021 giật... Ở Việt nam, các nghiên cứu về tiên lượng của trang thái cai rượu còn hạn chế. Mục tiêu nghiên cứu: mô tả đặc điểm lâm sàng và phân tích yếu tố tiên lương trang thái cai rươu trên bênh nhân điêu trị nội trú. Đối tượng và phương pháp nghiên cứu: nghiên cứu mô tả cắt ngang 71 bênh nhân được chẩn đoán trạng thái cai rượu theo tiêu chuẩn ICD 10 điều tri nôi trú tai Bênh viển Bach mai từ tháng 08/2020 đến tháng $06 / 2021$. Kết quả: $100 \%$ bệnh nhân là nam giới, triệu chứng run chiếm $98,6 \%$, vã mồ hôi $97,2 \%$, mất ngủ 98,6\%, tăng huyết áp và mạch nhanh 70,4\%; tiền sử sảng rươu làm tăng nguy cơ sảng có ý nghĩa thống kê $(\mathrm{p}<0,001)$; giảm kali máu tăng nguy cơ sảng (OR:0,4; CI95\% 0,1-0,9; $\mathrm{p}=0,04)$; 